Greenhouse effect

\section{Methane linked to warming}

\section{Ralph J. Cicerone}

Methane is an important chemical in the atmosphere; it controls numerous chemical processes and species in the troposphere and stratosphere and its infrared spectrum makes it a strong greenhouse gas. There is compelling evidence that the concentration of methane has increased globally at a rate of about 1 per cent per year since $1978^{1}$ (and probably since the early $1950 \mathrm{~s}^{2}$ ) to about 1.70 parts per million (p.p.m.) in 1988. This rapid contemporary increase began 150-200 years ago, when the concentration was $0.65-0.70$ p.p.m. according to analysis of air trapped in dated polar ice cores ${ }^{3-5}$. Two new experimental studies by Stauffer et al. ${ }^{6}$ and Raynaud et al. ${ }^{7}$ extend the ice-core record back to 100,000 years before present $(\mathrm{BP})^{6}$ and $161,000 \mathrm{BP}^{7}$, through the last two major glaciated periods, $18,000 \mathrm{BP}$ and 150,000 BP. During glacial maxima, the methane concentration fell to 0.35 p.p.m. whereas during interglacial times it rose to 0.65 p.p.m., very near modern pre-industrial values. Thus, the present concentration and that projected for the future are well above any in charted Earth history.

Stauffer et al. ${ }^{6}$ analysed 24 ice-core samples from Antarctica and Greenland to find the methane pattern during the last glaciation and through the transition to the warmer interglacial. Their Antarctic data extend back to $51,000 \mathrm{BP}$, the Greenland data back to 100,000 BP. Generally, during the last glaciation, about $20,000 \mathrm{BP}$, the methane concentration was about 0.35 p.p.m., increasing to about 0.65 p.p.m. by $14,000 \mathrm{BP}$. Preceding the last glacial period, it was $0.45-0.50$ p.p.m.

A similar pattern emerges for the preceding glaciation through analysis of

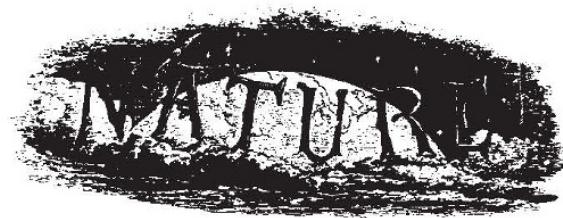

100 years ago

ON Thursday, the 12th inst., the anniversary meeting of the Sanitary Institution of Great Britain was held in the theatre of the Royal Institution. The Chairman, Mr, Edwin Chadwick, in opening the proceedings, claimed credit for the Sanitary Institution of Great Britain and like institutions for a large proportion of the reduced death-rate of the metropolis, which was now 14 in 1000 . London in that respect compared very favourably with other places, the death-rate in Paris being 27, Vienna 30 , and St Petersburg 40. Dr. B. W. Richardson delivered an address on "The Storage of Life as a Sanitary Study." He began by referring to the remarkable Vostok ice core from Antarctica. Raynaud et al. ${ }^{7}$ extracted methane from 27 core sections from the 155,000 -BP glaciated period, the following interglacial (about 130,000 BP) and the intervening transition period. During the glaciation the average methane concentration was 0.34 p.p.m., rising to 0.46 p.p.m. during the transition and 0.62 p.p.m. during interglacial times. Clearly, the natural methane background concentration during warm times is $0.6-0.7$ p.p.m. but is a factor of two lower during glacial epochs. There are even indications from Greenland cores that the concentration was low during a cold subinterval (Younger-Dryas period) of the present interglacial, and relatively high during a warm period of the last glaciation ${ }^{6}$. One measurement conflicts with this picture; it is the only previous methane concentration published $^{8}$ for a glacial period $(27,000 \mathrm{BP})$, measured as 0.65 p.p.m.

The analytical skill needed for these measurements deserves recognition. Even after a core is obtained and dated successfully, subsequent contamination, the gas-extraction method and chemical, biological or physical factors could all alter the methane content of the trapped $\operatorname{gas}^{3-7}$. All the indications are that the methane found in the ice cores does truly represent the composition of the atmosphere on the date of firn closure, when the compacting ice enclosed the gas and became impermeable.

Now that we know that the concentration of methane doubled between the lows and interglacial highs, and halved again, we can ask why and use this information to elucidate several components of the

instances of long life in lower animals and in man. These, he said, by some peculiar process as yet but little investigated, held life as a long profession, and to this faculty he applied the term "The Storage of Life." The problem which the lecturer placed before the society was stated as follows:- Certain proofs of the power of the human body to lay or store up life to a prolonged period are admitted. What are the conditions which favour such storage, and how can we promote the conditions which lead to it? He stated the conditions in the following order, hereditary qualifications, the virtue of continence, maintenance of balance of bodily functions, perfect temperance, and purity from implanted or acquired diseases. In dealing with all-round temperance, he showed that whatever quickened the action of the heart beyond its natural speed and force was a stimulant, and in proportion to the unnatural tax inflicted by stimulation there was a reduction in the storage of life

From Nature 38, 276; 19 July 1888
Earth's climate and biogeochemistry. The rate of microbial methanogenesis generally increases with temperature. Also, because the dominant methane sources are on land and not in the oceans ${ }^{8}$, these sources should be reduced when wetland soils are ice-covered or frozen, sealed off from the atmosphere. Thus our general knowledge of natural sources of methane is consistent with the new ice-core data.

But the principal sink of atmospheric methane, reaction with hydroxyl $(\mathrm{OH})$ radicals in the troposphere, should also increase with temperature for two reasons. First, the atmospheric $\mathrm{OH}$ concentration generally increases with that of $\mathrm{H}_{2} \mathrm{O}$, rising with temperature. Second, the rate constant for the reaction of $\mathrm{CH}_{4}$ with $\mathrm{OH}$ also increases with temperature. But the $\mathrm{OH}$ concentration also depends strongly on the amounts of ozone and nitrogen oxide present and the intensity of ultraviolet light. Without a knowledge of these, it is not possible to predict how atmospheric methane destruction rates respond to temperature perturbations.

A warmer Earth with more wetlands would provide more anoxic sites for anaerobic methanogenic bacteria. Overall rates of biological carbon cycling could also be larger. Ice-core $\mathrm{CO}_{2}$ data have shown a pattern similar to that of methane'. Both the oxic and anoxic paths of carbon cycling could be slowed during glaciation. The extent to which the decrease (or increase) of $\mathrm{CO}_{2}$ concentration actually causes glaciation (or deglaciation) is still debated, but we know now that the greenhouse effects of altered $\mathrm{CH}_{4}$ must accompany and add to those of $\mathrm{CO}_{2}$ changes. It is dangerous to argue, though, that other indirect effects would ensue. For example, increased $\mathrm{CH}_{4}$ need not have led to more tropospheric ozone (another greenhouse gas), as has been proposed $^{7}$, because in past epochs there may not have been sufficient atmospheric $\mathrm{NO}_{x}$ to allow this ${ }^{10}$. But it is sobering to learn that the methane concentration, like those of carbon dioxide and chlorofluorocarbons, has already increased to values above those of at least the past 160,000 years and that human activities are clearly involved in these global changes ${ }^{4.8}$.

Blake, D. R. \& Rowland, F.S. Science 239, 1129-1133 (1988).

2. Rinsland, C.P., Levine, J.S. \& Miles, T. Nature 318, 245 249 (1985)

3. Craig, H. B. \& Chou, C. C. Geophys. Res. Lett. 9, 1221 $1224(1982)$

Rasmussen, R. A. \& Khalil, M. A. K. J. geophys, Res. 89 $11599-11605$ (1984)

Stauffer, B., Fischer, G., Neftel, A. \& Oeschger, H Science 229, $1386-1388(1985)$

6. Stauffer, B., Lochbronner, E., Oeschger, H. \& Schwander J. Nature 332, 812-814 (1988).

. Raynaud, D., Chappellaz, J., Barnola, J., Korotkevich, J. S. \& Lorius, C. Nature 333, 655-657 (1988)

8. Ehhalt, D. H Tellus 26,58-70(1974)

9. Lorius, C. et al. Nature 316,591-596(1985)

10. Volz, A. \& Kley, D. Nature 332, 240-242 (1988)

Ralph J. Cicerone is at the National Center of Atmospheric Research, PO Box 3000, Boulder, Colorado 80307, USA. 